\title{
Травма, травматичний шок. Діагностика та надання невідкладної допомоги
}

\author{
І.С. Зозуля, А.О. Волосовець, А.І. Зозуля
}

Національний університет охорони здоров'я України імені П.Л. Шупика, Київ, Україна

\section{Вступ}

В усіх країнах світу відмічається зростання травматизму. В Україні він зумовлений збройним конфліктом на сході країни, зростанням дорожньо-транспортного травматизму. Щорічний приріст хворих, які перенесли травму головного мозку, за даними Всесвітньої організації охорони здоров'я, за останні роки збільшився на 2\%. У загальній структурі травматизму черепномозкова травма (ЧМТ) займає провідне місце (38-40\%). її частка становить $2 / 3$ летальних випадків, тому ЧМТ образно називають «убивцею № 1» в осіб віком <45 років. Україна займає провідне місце за кількістю постраждалих і загиблих у результаті дорожньо-транспортних пригод (ДТП). Згідно з даними статистики за останні 5 років зареєстровано $>170$ тис. ДТП. $43 \%$ травмованих - пішоходи та велосипедисти. Збитки від ДТП становлять $>2 \%$ ВВП, матеріальні збитки від аварій на дорогах - 40 млрд грн на рік. Важливе значення в ДТП має людський фактор. У $1 / 4$ постраждалих і травмованих виникає травматичний шок із загальною летальністю до 7,4\%.

У загальній структурі травматизму 30-50\% припадає на ЧМТ. У структурі смертності травматизм займає 3-тє місце, поступаючись серцево-судинним захворюванням і злоякісним новоутворенням.

Серед осіб, що вижили, тільки 10\% можуть повернутися до попередньої роботи і лише $2 \%$ задоволені якістю життя.

\section{ЧMT}

Розвернутий діагноз ЧМТ повинен складатися з 4 основних частин.

1. Загальна характеристика травми:

1.1. Ізольована ЧМТ - при ураженні тільки голови. Сполучна ЧМТ - при наявності ураження голови і позачерепних ушкоджень (тулуба, кінцівок). Комбінована ЧМТ - при одночасній дії різних факторів (механічний, термічний, хімічний, радіаційний).

1.2. Первинна ЧМТ, що виникає вперше в результаті нещасного випадку або навмисного ураження. Вторинна - при падінні і втраті свідомості в результаті гострого церебрального або іншого захворювання.

1.3. Закрита ЧМТ - характеризується відсутністю пошкодження цілісності м'яких покривів голови або пораненням м'яких покривів голови, але без ураження апоневрозу. Відкрита - при пораненні м'яких покривів голови, апоневрозі або переломі кісток сплетіння черепу, переломі кісток основи черепа з наявністю ліквореї. Проникаюча - відкрита ЧМТ з порушенням цілісності твердої мозкової оболонки. Непроникаюча - відкрита ЧМТ без ураження твердої мозкової оболонки.

2. Тяжкість чМТ визначають за шкалою коми Глазго: легка, середньої тяжкості і тяжка. Встановлення тяжкості ЧМТ має значення для визначення тактики ведення пацієнтів. Тяжкість ЧМТ визначають з врахуванням наступних факторів: час втрати свідомості (коматозного стану), ступінь пригнічення свідомості на час первинного огляду або госпіталізації, тривалість післятравматичної (антероградної) амнезії, вираженість вогнищевої неврологічної симптоматики, насамперед пов'язаної з ураженням діенцефально-стовбурових структур.
3. Наявність субарахноїдального крововиливу.

4. Наявність системних ускладнень.

Післятравматична амнезія триває <1 год. До легкої ЧМТ відносять струс головного мозку і забій головного мозку легкого ступеня. При легкій ЧМТ можуть бути лінійні переломи кісток склепіння черепа, помірні субарахноїдальні крововиливи. При ЧМТ середньої тяжкості втрата свідомості може бути протягом 30 хв-1 год. При первинному огляді визначається втрата свідомості у вигляді приглушення або сопору. За шкалою коми Глазго 8-12 балів. Час післятравматичної амнезії становить 1-24 год.

До ЧМТ середньої тяжкості відносять забій головного мозку середнього ступеня, при якому можливі субарахноїдальний крововилив, перелом кісток склепіння або основи черепа, помірне порушення життєво важливих функцій.

При тяжкій ЧМТ час втрати свідомості може становити декілька діб. За шкалою коми Глазго - 3-8 балів, амнезія $\geq 1$ доби. До тяжкої ЧМТ відносять забій головного мозку тяжкого ступеня, гостре стиснення головного мозку, субарахноїдальний крововилив, симптоми ураження життєво важливих функцій. Ускладнення ЧМТ можуть бути внутрішньочерепні інфекційні (менінгіт, абсцес), а також неінфекційні (набряк головного мозку, дислокація мозку, гідроцефалія). Позачерепні ускладнення - гіпоксія, вегетативні розлади, нейрогенний набряк легень, пневмонія, водно-електролітні порушення, шлунково-кишкова кровотеча, дисеміноване внутрішньосудинне згортання крові.

У перебігу ЧМТ виділяють такі періоди: гострий (2-10 тиж, можливий розвиток ускладнень, вторинного ураження головного мозку), проміжний (2-6 міс - період найбільш активного відновлення) та віддалений ( $\geq 1$ року - у випадку незворотних залишкових явищ прогресуючих ускладнень після травми).

Надання невідкладної допомоги здійснюється за системою ABCDE. У якості гіперосмолярної терапії рекомендовано застосовувати манітол в дозі 0,1-1,0 г/кг маси тіла, при цьому не допускати зниження систолічного артеріального тиску (АТ) $<90$ мм рт. ст. При тяжкій чМТ рекомендовано застосовувати анестетики, анальгетики, седативні препарати, окрім барбітуратів і стероїдних препаратів. Для профілактики тромбозу глибоких вен можна застосовувати гепарин у низьких дозах в комплексі з механічною профілактикою. При судомах - діазепам, вальпроєву кислоту. Рекомендовано нейропротектори у відновний період (цитиколін, едаравон та ін.).

Рекомендують магнію сульфат внутрішньовенно 10 мл 25\% розчину в 100 мл ізотонічного розчину, налоксон підшкірно 0,4 мг (1 мл), препарат есцинової солі 2,6-діаміногексанової кислоти внутрішньовенно крапельно 10 мл 0,1\% розчину.

Здійснюється госпіталізація в реанімаційне або нейрохірургічне відділення, де проводять комп'ютерну томографію, магнітно-резонансну томографію, при необхідності спинномозкову пункцію, рентгенографію шийного відділу хребта.

При 8 балах за шкалою коми Глазго здійснюють інтубацію трахеї, штучну вентиляцію легень (ШВЛ), поряд 3 цим вводять тіопентал натрію, пропофол. При систолічному АТ $<180$ мм рт. ст. - не знижувати. Для зниження АТ застосовують лабеталол, метопролол. При декомпенсованому шоку (систолічний АТ <65 мм рт. ст.) вводять допамін з добутаміном 5-10 мг, дексаметазон внутрішньовенно 4-8 мг (1-2 мл). 


\section{Спінальна травма}

Травми хребта та спинного мозку (СМ) належать до категорії тяжких ушкоджень, які у більшості випадків призводять до стійкої втрати працездатності або смерті. Травми хребта та СМ розділяють на відкриті з порушенням цілісності шкірних покривів у місці травми і закриті - без порушення цілісності шкірних покривів. До відкритих ушкоджень хребта належать вогнепальні поранення та колото-різані рани, при ДТП пов'язані з механічною травмою. Ці порушення, у свою чергу, розподіляють на проникаючі, якщо шкірна рана сполучається з субарахноїдальним простором, і непроникаючі - у протилежному випадку.

Найпоширенішими механізмом закритої травми хребта $\epsilon$ надмірне згинання у найбільш рухливих відділах під впливом травмуючого фактора, що перевищує максимальний об'єм фізіологічного згинання. Таке згинання призводить до пошкодження кісткових структур хребта. Це частіше відбувається на рівні $\mathrm{C}_{\mathrm{v}}-$ $\mathrm{C}_{\mathrm{VII}} \mathrm{Th}_{\mathrm{xII}} \mathrm{L}_{1}$-хребцців.

При закритих ушкодженнях хребта та СМ розрізняють ушкодження без порушення функції СМ, з порушенням функції СМ та його корінців без травми хребта.

За рівнем та ступенем провідності виділяють ушкодження шийного, грудного, попереково-крижового відділу хребта, СМ і «кінського хвоста». За ступенем порушення провідності СМ виділяють типи з повним порушенням провідності СМ, частковим її порушенням і відсутністю таких порушень. За характером ушкоджень анатомічних утворень хребта виділяють ушкодження зв'язкового та зв'язково-суглобового апарату з вивихами та підвивихами хребців, щілини міжхребцевих дисків та зсувів, тіл хребців у виглядів тріщин, переломів (компресійних, уламкових та поперечних), переломи дужок у суглобових, поперекових та остистих відростках, комбіновані переломи тіл та дужок із зсувом та без такого. В окрему групу виділяють тяжкі комбіновані ушкодження хребта, СМ, внутрішніх органів, грудної та черевної порожнини, які супроводжуються внутрішньою та зовнішньою кровотечею, скелетною травмою та ЧМТ.

Комплекс патофізіологічних змін в організмі при травмі СМ має назву «травматичне захворювання спинного мозку». Виділяють гострий період (2-3 доби, характеризується типовою картиною спінального шоку), ранній період (2-3 тиж, характеризу$\epsilon$ ться синдромом порушення провідності СМ, зумовлений його ушкодженням - спінальний шок, що сформувався), проміжний період (до 2-3 міс, характеризується зникненням явищ спінального шоку та установленням справжнього характеру ушкодження СМ) і пізній період (з 3-4 міс та триває невизначено довго, у цей період відбувається дуже повільне відновлення функції CM, автоматизму нижче рівня ушкодження).

Невідкладну допомогу після травми хребта та СМ надають у перший період, тобто у хворих зі спінальним шоком, за системою $A B C D E$.

На догоспітальному етапі постраждалого слід покласти на щит і транспортувати у відділення неврології або нейрохірургії через відділення невідкладної допомоги (приймальне). Треба встановити, чи $\epsilon$ у постраждалого струс, забій чи стиснення СМ. Вже в приймальному відділені постраждалого оглядає мультидисциплінарна бригада, проводять спіральну комп'ютерну томографію, магнітно-резонансну томографію, рентгенографію.

При спінальному шоку виникає гальмування функції СМ нижче рівня його ураження. Глибина та тривалість спінального шоку залежать від тяжкості та рівня травми СМ у вигляді парезу, параплегії, гіпестезії та анастезії, трофічних розладів та порушення функції тазових органів. Тривалість спінального шоку в середньому становить від декількох днів до 2-8 тиж. За наявності у ділянці травми різних подразників (гематома, кісткові відламки, чужорідні тіла) явища спінального шоку можуть зберігатися упродовж декількох місяців та навіть років. Під їх впливом парабіоз може стати незворотним зі стійкою втратою збудливості, загибеллю елементів СМ.

Повний анатомічний розрив СМ супроводжується тривалим шоком, різким зниженням тонусу м'язів в паралізованих кінцівках, відсутністю рефлексів. Ушкоджуються як провідні шляхи, що несуть імпульси до центральної нервової системи (ЦНС), так і ті, по яких здійснюється регулююча дія кори головного мозку. Це також значною мірою позначається на функції внутрішніх органів (з боку серцево-судинної системи аж до її декомпенсації). Найбільш виражені порушення серцевої діяльності відмічають у хворих з ураженням нижньошийного і верхньогрудного відділів.

У хворих з ушкодженнями хребта та СМ виділяють 2 типи порушень дихання - центральний і периферичний. Чим вищий рівень травми, тим більшим $\epsilon$ порушення дихання. При травмі високого рівня у шийному відділі можливий висхідний набряк СМ з переходом на стовбур головного мозку і компресією життєво важливих центрів, в першу чергу порушення дихання за центральним типом. При травмі хребта і СМ порушується функція моторики шлунка та кишечнику, підшлункової залози, надниркових залоз, відбуваються циротичні зміни у печінці, виникають множинні крововиливи і гострі виразки шлунка, набряк легень, пневмонія.

На догоспітальному етапі надзвичайно важливо відрізнити за клінічною картиною фізіологічне переривання СМ від морфологічного. Слід зазначити, що в гострий період картина «повного переривання» провідності може спостерігатися при різних формах ушкодження СМ - від струсу до його стиснення.

Повне порушення характеризується в'ялим симетричним паралічем м'язів нижче рівня ушкодження, зникненням всіх видів чутливості за провідниковим типом та всіх рефлексів, трофічними розладами та тяжкими порушеннями функції тазових органів.

Може виникати синдром часткового порушення провідності СМ. Він характеризується неповним зникненням тієї чи іншої функції. Виявляють парези м'язів різного ступеня вираженості, а розлади чутливості можуть бути самими різноманітними. Половинне ураження має назву синдром Броуна - Секара.

До найчастіших клінічних форм ушкодження СМ належать струс, забій і стиснення.

В основі патофізіологічних змін струсу СМ - його зворотні порушення за типом парабіозу і позамежового гальмування, що проявляється синдромом часткового або повного порушення провідності з минущими парезами або паралічами, розладами чутливості, іноді у вигляді парестезій, тимчасовим порушенням функції тазових органів. Через 3-5 діб ці порушення регресують. Аналіз спинномозкової рідини не виявляє ознак патології. Повне відновлення порушених функцій СМ відрізняє струс головного мозку від забою.

Забій СМ найчастіше виявляють при закритих ушкодженнях хребта. Проявляється у вигляді незворотних морфологічних змін (некроз, крововилив) у поєднанні зі змінами зворотного характеру. Клінічно забій СМ найчастіше проявляється синдромом повного порушення провідності, уточнити характер якого в гострий період травми дуже важко. Спинномозкова рідина у таких хворих має кров'янисте забарвлення внаслідок ушкодження судин СМ, субарахноїдального крововиливу.

Стиснення СМ $\epsilon$ найтяжчим його ушкодженням. СМ стискається внаслідок закритих та відкритих травм хребта зі зміщенням відламків дужок або тіл хребців, гострим грижовим випадінням дисків, вогнепальних поранень, проникнення чужорідних металевих тіл. Можуть виникати епідуральні гематоми. У цьому випадку хворий безпосередньо після травми ще може пересуватися самостійно. У подальшому у міру збільшення гематоми у нього погіршуються явища парезів та паралічів.

Невідкладну допомогу здійснюють за системою ABCDE. Необхідно швидко установити діагноз з наступним усуненням розладів дихання та кровообігу, які становлять загрозу для життя. Необхідно оцінити тяжкість стану хворого, визначити, чи потребує хворий реанімаційних заходів, вирішити питання про послідовність невідкладних заходів у зв'язку з тим, які порушення життєво важливих функцій потребують негайної корекції. 3'ясувати характер травми, визначити, має місце «чиста» спінальна травма чи вона поєднана з іншими ушкодженнями. У разі поєднаної травми необхідно здійснити заходи, які спрямовані 
на усунення патології, що є супутньою спінальній травмі: зупинити кровотечу, усунути гостру дихальну недостатність, компенсувати гіповолемію. Інтубацію (за необхідності) здійснюють на фоні спонтанного дихання (без застосування м'язових релаксантів), а при частково збереженій свідомості - в умовах наркозу (20\% розчином натрію оксибутирату або $0,5 \%$ розчином діазепаму).

При травмі хребта в шийному та верхньогрудному відділах маніпуляції з метою відновлення прохідності дихальних шляхів проводять з крайньою обережністю. У такому випадку більш доцільною $є$ термінова трахеотомія або конікотомія.

Апное, термінальний тип дихання, тахіпное >40-50 дихальних рухів за 1 хв і брадипное $<10$ за 1 хв $\in$ показанням до проведення ШВЛ за допомогою маски, наркозного апарату, ендотрахеальної трубки або трахіостоми чи конікотоми.

При розвитку термінального стану необхідна серцево-легенева реанімація у поєднані з екстренним усуненням дефіциту об'єму циркулюючої крові (ОЦК). Кінцевий етап надання догоспітальної допомоги включає заходи, що спрямовані на ефективне знеболення, якісну іммобілізацію, обережне укладання хворого на носилки у функціонально вигідному положенні тіла. Для знеболення застосовують закис азоту, кетамін, метамізол натрій, при тривалому транспортуванні - натрію оксибутират, діазепіни. Морфін, омнопон, буторфанолу тартрат не слід застосовувати через їх властивість пригнічувати дихальний центр. Транспортування хворого з травмою хребта і СМ повинно здійснюватися тільки у разі іммобілізації.

3 метою іммобілізації при переломах грудного та поперекового відділів хребта при транспортуванні використовують жорсткі носилки та різного роду щити, на які постраждалого укладають на спину або живіт. Для запобігання зсуву відламків хребців недопустимим $\epsilon$ транспортування хворого у положенні на боку.

Піднімати хворого на носилки необхідно відразу в один захід (3-5 осіб), обов'язково підтримуючи голову хворого (особливо при травмі у шийному відділі). Небажаним $€$ повторне, тим більше багаторазове, перекладання пацієнта. Потрібно дотримуватися правила «потерпілого з травмою хребта та СМ укладати на носилки (щит) лише один раз». При травмі хребта і СМ (корінців) у грудному і поперековому відділі транспортувати на щиті у положенні на спині, при відсутності щита — на животі.

При травмі у шийній ділянці транспортування повинно проводитися у положенні хворого на спині незалежно від наявності щита і з мобілізацією комірцем.

При травмі хребта без ушкодження СМ призначають препарат метамізолу натрію, пітофенону гідрохлориду та фенпіверинію броміду 5 мл внутрішньовенно або внутрішньом'язово, метамізол натрій 50\% 2 мл внутрішньовенно, закис азоту з киснем у співвідношенні 2:1 через маску наркозного апарату, шийний комірець (незалежно від рівня ушкодження хребта), транспортування у нейрохірургічне або травматологічне відділення.

При травмі хребта з ушкодженням СМ слід виключити супутню патологію, у разі наростання дихальної недостатності внаслідок напруженого пневмотораксу - термінова пункція та катетеризація плевральної порожнини у II міжреберному проміжку по середньоключичній лінії.

При наростаючій гострій дихальній недостатності внаслідок гемотораксу - термінова пункція плевральної порожнини у VI-VII міжреберному проміжку по задній аксилярній лінії. При необхідності - конікотомія та ендотрахеальна трубка. При травмі у шийному відділі хребта ендотрахіальну інтубацію здійснюють украй обережно, не натискаючи на голову хворого. У цьому випадку більш доцільною $\epsilon$ конікотомія з використанням спеціального конікотома. У разі збільшення числа дихальних рухів $>40-50$ або $<10$ за 1 хв показана ШВЛ.

Зупинити зовнішню кровотечу. При рівні систолічного АТ $<90$ мм рт. ст. - поліглюкін, розчин Хартмана та інші розчини електролітів. Швидкість та об'єм інфузії підбирати так, щоб АТ становив >90 мм рт. ст. При необхідності вводять вазопресори (норадреналін, фенілефрин) 1,0-3,0 мл в одній з плазмозаміщуючих речовин. Метилпреднізолон внутрішньовенно до 30-40 мг за період надання допомоги. Кетамін у дозі 2 мг/кг маси тіла внутрішньовенно або 4,6 мг/кг маси тіла внутрішньом'язово. При необхідності вводять діазепам у дозі 0,5 мг/кг маси тіла + натрію оксибутират 50-80 мг/кг маси тіла внутрішньовенно (у разі транспортування хворого $>2$ год).

Накладають шийний комірець, обережно укладають хворого на носилки (щит) і транспортують у багатопрофільний стаціонар (реанімаційне або нейрохірургічне відділення) у разі відновлення систолічного АТ не менше 90 мм рт. ст. та при адекватній вентиляції легень.

Основні принципи лікування травми хребта і СМ в стаціонарі - намагатися підтримувати газообмін в легенях та гемодинаміку на адекватному рівні, проводити протинабрякову терапію, профілактику ускладнень (гостра пневмонія, уросепсис, пролежні, серцево-судинна недостатність).

При гострій дихальній недостатності $\left(\mathrm{PaO}_{2}<60\right.$ мм рт. ст., $\mathrm{PaCO}_{2}>60$ мм рт. ст.) слід переходити на ШВЛ. При зниженні рівня AT показано призначення вазопресорів, глюкокортикоїдів (метилпреднізолон) 4-8 мг/кг маси тіла. Для інфузійної терапії застосовують високомолекулярні декстрани, альбумін, концентровану плазму крові.

Протинабрякову терапію здійснюють салуретиками (манітол, фуросемід, препарат есцинової солі).

Профілактику та інтенсивну терапію гострої пневмонії здійснюють за загальноприйнятою схемою.

3 метою профілактики уросепсису необхідно забезпечити постійне промивання сечового міхура через систему Монро.

При травмі хребта і СМ може виникати гематомієлія, при якій уражаються сіра речовина СМ (частіше задні роги). Основні ознаки гематомієлії - дисоційовані розлади чутливості, які мають сегментарний характер, у поєднанні з парезами та паралічами відповідно до уражених сегментів. Вона може призвести до повного або часткового порушення провідності. Лікування гематомієлії консервативне або оперативне (індивідуально).

\section{Травматичний шок}

Травматичний шок - фазовий патологічний процес, що супроводжується змінами гомеостазу у вигляді порушення гемодинаміки, дихання, нейроендокринних порушень, обміну речовин, функцій життєво важливих органів, імунологічного статусу.

Травматичний шок виникає при тяжких пораненнях і травмах у $1 / 3$ травмованих із загальною летальністю до 7,4\%.

Клінічні прояви і тяжкість травматичного шоку залежать від тяжкості травми та її локалізації. Порушення життєво важливих функцій при травматичному шоку має пролонгований лавиноподібний фазний характер і специфічний патогенез, що пов'язаний переважно з гіповолемією. Травматичний шок $\epsilon$ першим періодом травматичної хвороби.

На тяжкість клінічного перебігу травматичного шоку впливають такі чинники, як пізня і неповноцінна первинна медична допомога, повторна травматизація, охолодження та перегрівання, голодування, гіпо- та авітаміноз, фізична й емоційна перевтома. Клінічно розрізняють три фази травматичного шоку: еректильну, торпідну, термінальну.

У клінічному перебігу торпідної фази виділяють такі періоди: компенсований зворотний шок, декомпенсований зворотний шок і декомпенсований незворотний шок. У визначенні наслідків для життя виділяють сприятливий, сумнівний і несприятливий періоди.

За вираженістю виділяють 3 ступені травматичного шоку:

- I (нетяжкий): виникає при пораненнях середньої тяжкості з крововтратою 20-30\% ОЦК; свідомість збережена, може виникати психічна загальмованість; систолічний АТ 90-100 мм рт. ст., пульс 100-120 уд./хв, частота дихання до 25/хв; при своєчасному наданні медичної допомоги прогноз для життя сприятливий;

- II (тяжкий): крововтрата 30-40\% ОЦК; свідомість порушена, блідість шкіри, рухова і психічна загальмованість; АТ 70-90 мм рт. ст., пульс 120-140 уд./хв, дихання поверхневе, до 30/хв; прогноз для життя сумнівний; 
- III (вкрай тяжкий): крововтрата >40\% ОЦК; шкіра бліда, ціанотична, холодний піт, анурія, АТ <70 мм рт. ст., пульс 140 уд./хв, дихання до 40/хв; прогноз для життя несприятливий.

Термінальна фаза травматичного шоку ділиться на передагональний стан, агонію і стан клінічної смерті.

Передагональний стан характеризується комою, поверхневим рідкісним диханням. Пульс на периферичних артеріях не визначається, на сонній і стегнових - слабкий. Зіниці розширені, реагують на світло. АТ $<50$ мм рт. ст.

Агональний стан проявляється глибокою комою. Дихання майже непомітне. Пульс і АТ не визначаються, тони серця глухі. Зіниці розширені, слабо реагують на світло.

Клінічна смерть характеризується відсутністю зовнішніх ознак життя. Припинення дихання і серцевої діяльності, розширення зіниць і відсутність рогівкового рефлексу. Якщо не проводити реанімаційні заходи - через 5-7 хв розвиваються незворотні зміни в життєво важливих органах (ЦНС, печінка, нирки, серце). Настає біологічна смерть.

В основі діагностики і визначення ступеня тяжкості травматичного шоку лежать показники загального стану: зовнішній вигляд, частота дихання, систолічний АТ, частота пульсу. Вони залежать від розміру крововтрати і тяжкості гіповолемії.

Для орієнтовного визначення об'єму крововтрати визначають характер травми: зовнішня кровотеча, внутрішньогрудна, внутрішньочеревна. Найбільш об'єктивними показниками крововтрати $\epsilon$ гематокритне число (30-35\%), шоковий індекс Альговера, рівень гемоглобіну у крові. Шок випереджає артеріальну гіпотензію. Крім того, враховують шоковий індекс, погодинний діурез, порушення свідомості і психіки.

На II рівні допомоги при травматичному шоку проводять комплексну диференційну терапію. Швидка діагностика травматичного шоку, ранній початок загальних заходів первинної реанімації до встановлення етіологічного фактора: відновлення прохідності дихальних шляхів, забезпечення адекватного газообміну, кардіореанімація, екстрений гемостаз, підтримка ОЦК, іммобілізація переломів, знеболення, надання раціонального положення постраждалому. Проводять визначення провідних етіологічних факторів травматичного шоку: огляд постраждалого, оцінку тяжкості і характер травми. Катетеризація центральної вени, встановлення назогастрального зонда і катетеризація сечового міхура з контролем діурезу, проведення електрокардіограми, рентгенографія органів грудної клітки, ультразвукове дослідження органів черевної порожнини, при необхідності лапароцентез, плевральна пункція, торакоцентез.

Комплексна інтенсивна терапія травматичного шоку: зупинка зовнішньої або внутрішньої кровотечі, усунення пошкодження і тампонади серця, усунення гіповолемії і моніторинг ОЦК.

Гостру дихальну недостатність усувають за допомогою інгаляції кисню через 96\% етиловий спирт з одночасною аспірацією слизу з бронхіального дерева. Інтубацію трахеї проводять при тяжких пошкодженнях голови, обличчя і шиї, травмі грудної клітки.
Стабілізація гемодинаміки проводиться колоїдними розчинами на основі гідроксиетилкрохмалю та желатину. Для відновлення транскапілярного обміну і нормалізації водно-електролітного балансу застосовують кристалоїдні розчини (0,9\% розчин натрію хлориду, розчини Рінгера лактат, Хартмана, Дарроу та ін.).

Об'єм інфузії повинен бути значно більшим за дефіцит ОЦК. У перші години інфузію проводять зі швидкістю 2-4 л/год під контролем центрального венозного тиску. Якщо систолічний АТ і центральний венозний тиск залишаються низькими, то збільшують швидкість інфузії, проводячи ії в 2-3 вени одночасно.

Адекватне відновлення втраченої крові найбільш ефективне в перші 2 доби і поєднується із застосуванням препаратів, які стимулюють тонус периферичних судин: допамін у дозі 10-15 мкг/кг маси тіла за 1 хв, норадреналін 1,0-2,0 мл 0,2\% розчин в 400 мл 5\% глюкози зі швидкістю 40-50 крапель за 1 хв. При гострій масивній кровотечі (ОЦК >30\%) доцільно починати із струминного введення в 1-2 периферичні вени кристалоїдних, а потім колоїдних розчинів, щоб забезпечити об'ємну швидкість інфузії не менше 150 мл/хв.

Обсяг протишокової інфузійно-трансфузійної терапії при тяжкому і вкрай тяжкому шоку повинен включати в 1-шу добу натрію хлорид 0,9\% 7-10 мл/кг маси тіла, ксилітол+натрію ацетат 5 мл/кг маси тіла, колоїди 5-7 мл/кг маси тіла, еритроцитарну масу - 10 мл/кг маси тіла. Після стабілізації ОЦК і АТ проводять відновлення транскапілярного обміну шляхом інфузії нітрогліцерину (5-10 мкг/хв) у поєднанні з інфузією допаміну в інотропних дозах (5-10 мг/кг/хв). На адекватність капілярної перфузії вказують такі параметри: АТ >80-100 мм рт. ст., центральний венозний тиск 80-90 мм рт. ст., діурез >30 мл/кг. При появі брадикардії призначають інфузію ізопреналіну або атропіну.

Необхідно забезпечити знеболення: внутрішньовенне введення наркотичних препаратів (промедол 2\% 1-2 мл, морфіну гідрохлорид 1\% 1 мл) або трамадол 2\% 1-2 мл, анальгетики, нейролептанальгезія із застосуванням дроперидолу і фентанілу 0,005\% 1-2 мл. Проводять усунення порушень діяльності ЦНС і нейроендокринної регуляції шляхом введення натрію оксибутирату, діазепінів, нейролептиків, антигістамінних препаратів.

Корекцію метаболічних порушень здійснюють після відновлення ОЦК за допомогою розчину гідрокарбонату натрію, розчину Рінгера лактату, ксилітолу+натрію ацетату та ін.

Компенсацію іонів калію здійснюють тільки при добовому діурезі не менше 500-700 мл, калій обов'язково вводять, якщо постраждалому призначені глюкокортикоїди (5 г хлориду калію на добу).

Таким чином, профілактика травматичного шоку розпочинається з моменту надання само- та взаємодопомоги шляхом тимчасової зупинки кровотечі, застосування анальгетиків, адекватної іммобілізації кінцівок. Інфузійно-трансфузійну терапію травматичного шоку слід розпочинати якомога раніше, але вона не повинна бути причиною затримки евакуації (транспортування).

\section{Відомості про авторів:}

Зозуля Іван Савович - доктор медичних наук, професор кафедри медицини невідкладних станів Національного університету охорони здоров'я України імені П.Л. Шупика, Київ, Україна. Волосовець Антон Олександрович — доктор медичних наук, доцент, завідувач кафедри медицини невідкладних станів Національного університету охорони здоров'я України імені П.Л. Шупика, Київ, Україна.

Зозуля Андрій Іванович — доктор медичних наук, професор кафедри медицини невідкладних станів Національного університету охорони здоров'я України імені П.Л. Шупика, Київ, Україна.

\section{Адреса для кореспонденції:}

Зозуля Іван Савович

04112, Київ, вул. Дорогожицька, 9

E-mail:nmapo.emergency@gmail.com

\section{Information about the authors:}

Zozulya Ivan S. - Doctor of Medical Sciences, Professor of the Department of Emergency Medicine of the Shupyk National Healthcare University of Ukraine, Kyiv, Ukraine.

Volosovets Anton 0. - Doctor of Medical Sciences, Associate Professor, Head of the Department of Emergency Medicine of the Shupyk National Healthcare University of Ukraine, Kyiv, Ukraine.

Zozulya Andriy I. - D Doctor of Medical Sciences, Professor of the Department of Emergency Medicine of the Shupyk National Healthcare University of Ukraine, Kyiv, Ukraine.

Address for correspondence:

Ivan Zozulya

04112, Kyiv, Dorohozhytska str., 9

E-mail: nmapo.emergency@gmail.com 
ТЕСТОВІ ЗАПИТАННЯ

(один або декілька правильних варіантів відповідей на кожне запитання)

1. Усі травми хребта та СМ розподіляють на:
$\square$ відкриті
$\square$ закриті
$\square$ без порушення функції СМ
$\square$ з порушенням функції СМ
$\square$ всі відповіді вірні

2. За ступенем порушення провідності СМ ушкодження бувають:
$\square \quad$ повним порушенням провідності
з з частковим її порушенням
ㄱ в відсутністю порушень провідності
$\square$ у вигляді синдрому Броуна - Секара

3. Комбіновані ушкодження проявляються ураженням:
$\square$ хребта
$\square \mathrm{CM}$
$\square$ внутрішніх органів
$\square$ грудної та черевної порожнини
$\square$ радіаційним ураженням

4. Травматичне ураження СМ ділиться на періоди:
$\square$ гострий (2-3 доби)
$\square$ ранній (2-3 тиж)
$\square$ проміжний (2-3 міс)
$\square$ пізній (з 3-4 міс)
$\square$ відновний

5. Спінальний шок проявляється:

$\square$ головним болем

$\square$ порушенням провідності і рефлекторної діяльності

$\square$ парезами, паралічами

$\square$ анестезією і гіпестезією

$\square$ розладом функції тазових органів

6. Функціональні розлади як наслідок травми виявляють у вигляді:

$\square$ порушень з боку серцево-судинної системи (аж до декомпенсації)

$\square$ погіршення зору

$\square$ змін судинного тонусу

$\square$ порушень дихання

$\square$ порушень моторики шлунка та кишечнику

$\square$ порушень функції підшлункової залози

7. Половинне ураження спинного мозку (синдром Броуна

- Секара) характеризується:

$\square$ руховими порушеннями на боці ураження

$\square$ порушенням больової чутливості на протилежному боці на 2 сегменти нижче

$\square$ порушенням функції тазових органів

$\square$ запамороченням

8. Клінічні форми ушкодження СМ:
$\square$ струс
$\square$ забій
$\square$ гематомієлія
$\square$ стиснення

9. Стиснення СМ зумовлюється:

$\square$ зміщенням відламків дужок або тіл хребта

$\square$ гострими грижовими випаданнями дисків

$\square$ вогнепальними пораненнями

$\square$ проникненням чужорідних металевих тіл

$\square$ гематомою

$\square$ зламаним ребром

10. Переведення хворого на ШВЛ показане при:

$\square$ кашлю
$\square$ апное
$\square$ термінальному типі дихання
$\square$ тахіпное (>40-50 за 1 хв)
$\square$ брадипное $(<10$ за 1 хв)

11. Кінцевий етап надання догоспітальної допомоги включає:

$\square$ ефективне знеболення

$\square$ якісну іммобілізацію

$\square$ обережне укладання хворого на носилки (3-4 чоловіки, 1 раз, не перекладаючи)

$\square$ госпіталізацію в реанімаційне або нейрохірургічне відділення

$\square$ накладання джгута

12. Класифікація ЧМТ:
$\square$ ізольована
$\square$ сполучна
$\square$ комбінована
$\square$ первинна
$\square$ вторинна
$\square$ відкрита
$\square$ закрита
$\square$ проникаюча
$\square$ непроникаюча
$\square$ всі відповіді вірні

13. Тяжкість ЧМТ визначається:

$\square$ часом втрати свідомості

$\square$ ступенем пригнічення свідомості на момент огляду

$\square$ тривалістю післятравматичної амнезії

$\square$ наявністю порушень сечовиділення

$\square$ вираженістю вогнищевої неврологічної симптоматики

$\square$ наявністю субарахноїдального крововиливу

14. За тяжкістю ЧмТ ділиться на:
$\square$ легку
$\square$ середньої тяжкості
$\square$ тяжку
$\square$ невизначену

15. Внутрішньочерепні ускладнення ЧМТ:
$\square$ менінгіт, абсцес
$\square$ набряк головного мозку
$\square$ дислокація головного мозку
$\square$ гідроцефалія
$\square$ пухлина головного мозку

16. Позачерепні ускладнення ЧМТ:

$\square$ гіпоксія

$\square$ вегетативні розлади

$\square$ пневмонія

$\square$ набряк легень

$\square$ порушення акту дефекації

$\square$ шлунково-кишкова кровотеча

17. Перебіг ЧМт:
$\square$ гострий період (2-10 тиж)
$\square$ проміжний (2-6 міс)
$\square$ віддалений ( $\geq 1$ року)
$\square$ невизначений

18. Діагностика травматичного шоку базується на показниках:

$\square$ зовнішнього вигляду постраждалого

$\square$ систолічного АТ

$\square$ частоти дихання та пульсу

$\square$ діурезу 
19. Найбільш об'єктивні показники крововтрати:
$\square$ рівень видихуваного кисню
$\square$ гематокритне число (30-35\%)
$\square$ шоковий індекс Альговера
$\square$ рівень гемоглобіну

20. Ранні загальні заходи:
$\square$ відновлення прохідності дихальних шляхів
$\square$ забезпечення адекватного газообміну
$\square$ кардіореанімація
$\square$ підтримка ОЦК
$\square$ анальгезія
$\square$ всі відповіді вірні

21. Травматичний шок зумовлений порушенням:
$\square$ гемодинаміки
$\square$ дихання
$\square$ нейроендокринними розладами
обміну речовин
$\square$ сечовиділення

22. На тяжкість клінічного перебігу травматичного шоку впливають:

$\square$ пізня і неповноцінна медична допомога

$\square$ повторна травматизація

$\square$ крововтрата

$\square$ порушення зору

$\square$ переохолодження і перегрівання

23. Які фази травматичного шоку виділяють?
$\square$ еректильну
$\square$ торпідну
$\square$ термінальну
$\square$ невизначену

24. Ступені тяжкості травматичного шоку:
ㄱ I (крововтрата 20-30\% ОЦК)
口 II (тяжкий) - крововтрата 30-40\% ОЦК
$\square$ всі відповіді вірні

\author{
Для отримання сертифіката дайте відповідь \\ на тестові запитання в режимі on-line \\ на сайті журналу \\ www.umj.com.ua \\ або надішліть ксерокопію сторінок \\ з відповідями разом з контактною \\ інформацією за адресою: \\ 01001, Київ-1, a/c «В»-82, ТОВ «МОРІОН»
}

ПІБ
Поштова адреса: індекс
область
район
місто
вулиця
будинок
квартира

Teлефон
E-mail

